Introduction to Special Issue of Citizenship Studies on "Citizenship, Learning and Education" (edited by Rachel Brooks \& John Holford)

\title{
Citizenship, Learning, Education: Themes and Issues
}

\author{
Rachel Brooks ${ }^{1}$ and John Holford ${ }^{2}$
}

\section{Introduction}

The explosion of sociological, political and legal literature on citizenship over the past decade has been paralleled in many countries by policy initiatives to develop and extend citizenship education. Recent years have also witnessed a burgeoning of research on citizenship and education: new international journals have been established (such as Education, Citizenship and Social Justice ${ }^{1}$ and Citizenship, Teaching and Learning ${ }^{2}$ ); the European Union has commissioned several large-scale research projects in this area ${ }^{3}$ and the International Association for the Evaluation of Educational Achievement is working on a is working on a comparative study of citizenship education in around 30 countries. There has, however, been surprisingly little recent cross-fertilisation between educational research on citizenship and

\footnotetext{
${ }^{1}$ Department of Political, International \& Policy Studies, University of Surrey, Guildford GU2 7XH.

R.Brooks@surrey.ac.uk

${ }^{2}$ School of Education, University of Nottingham, Jubilee Campus, Wollaton Road, Nottingham NG8 1BB. John.Holford@nottingham.ac.uk
} 
other areas of citizenship studies research. The purpose of this special issue of Citizenship Studies is to contribute to redressing this.

While many citizenship scholars seem broadly aware that 'citizenship' is of growing importance in educational curricula, few have attempted any systematic exploration of what this might imply. The exceptions almost prove the rule: Delanty (2003), for instance, argues in a brief paper for seeing 'citizenship as a learning process' (but this was an invited contribution to a special issue of an Education journal); Hoffman (2004) devotes three pages of his Citizenship beyond the State to an evaluation of the Crick Report. In contrast, citizenship education literature often refers to sociological writing; typically, however, it uses this almost symbolically, to provide theoretical authority or background. Too seldom do educational researchers use educational perspectives to contribute to debates on citizenship beyond the educational sphere: exceptions suggest the potential of such work (cf, e.g., Green, Preston \& Janmaat 2006, Lister et al. 2003). In funded research programmes, citizenship education tends to be treated as an aspect of educational research - and thus largely ignored by the wider social science community.

This special issue is based on the view that perspectives from educational research have much to contribute to the understanding of contemporary citizenship. Education, has, of course, been a recurring theme in philosophy and social theory of citizenship for millenia (Heater 2004); the recent tendency to 'separate development' is both odd and regrettable. The special issue has, therefore, three main aims: to provide Citizenship Studies readers, and thus the broader community of citizenship scholars, with insights into contemporary research on citizenship education; to provide analyses of contemporary international developments in citizenship education, covering a range of aspects of education; and to suggest how 
theoretical perspectives and empirical findings from learning and educational research on citizenship might contribute to broader citizenship scholarship.

The main purpose of this article is to introduce some of the key debates in the field, and signal the ways in which these are taken forward by the authors who have contributed to the special issue. We first consider some of the reasons why interest in citizenship education has grown over recent years, and how these have often been underpinned by a more general revival of interest in the concept of citizenship in many parts of the world. We also explore the idea of a 'learning society' and how this has impacted on citizenship education initiatives, at the level of both theory and practice. We then move on to consider some of the key debates about the content and nature of citizenship education that have engaged scholars in this area over recent years. In particular, we consider the location of citizenship education and the impact of context on the type of learning that takes place. We thus describe the ways in which it has been incorporated in both school-based education and post-compulsory, lifelong learning, and analyse the similarities and differences between these different forms of provision. We also outline some of the debates about whether citizenship is better learnt through formal or informal provision.

We then move on to consider more explicitly the content of citizenship education initiatives. Here, we focus on the tensions between emphasising knowledge transmission, on the one hand, and more practically-focussed 'active citizenship' on the other. We also consider some of the related debates about the extent to which citizenship education should focus on the rights of citizens vis-à-vis their responsibilities, and the capacity of citizenship education (in its various guises) to address structural inequalities within society. While citizenship education programmes have often been developed at the national level, there is considerable 
debate about whether initiatives would be better aimed at inculcating a sense of membership of other types of community. Indeed, there is now a growing literature on education for global citizenship, particularly in light of debates about post-national citizenship. This is explored in a later section of this article. Finally, we draw together these strands to consider some of the ways in which theoretical and empirical work on citizenship education can enrich the broader area of citizenship studies.

In parallel with the growth of policy and pedagogical interest in citizenship education, we have seen a marked growth in the volume of evidence available to inform discussion about it. Varied in nature and quality, this new evidence falls into several - overlapping and intersecting - categories. There are, first of all, studies of policy in citizenship education: its development and nature. There are studies of curriculum, and of teaching approaches and methods. There are evaluations of the impact and effect of policies and curricula, and attempts to explore what people (adults and children) learn as a result of the teaching of citizenship. There are studies of the content of citizenship learning, and of what knowledge, skills, attitudes and values 'educated' citizens might be expected to have. There is an increasing number not only of country-based studies, but of major comparative surveys. And 'behind' all of these is a range of historical and theoretical studies of the development of citizenship education, and what it might or should comprise.

This special issue seeks to illustrate, rather than to provide a detailed account of, or commentary on, this work. ${ }^{4}$ In a rapidly-developing area, research is conducted both within public sector universities and research institutes, and in the private and 'third' sector. It involves some curiosity-based scholarship, but the principal drivers are the demands of policy development and improved educational practice. For example, the Council of Europe's 
'Education for Democratic Citizenship' (EDC) project, initiated in 1996, was designed (inter alia) 'to actively encourage political leaders, decision-makers and people on the ground to treat EDC as a priority of educational policies' and 'to come to the aid of practitioners by providing them with the necessary tools: concepts, methods, political and legal references, examples, case studies, training materials, exchanges and networks'. In pursuit of these, it set out a range of goals for which research was essential:

- to define the conceptual framework, support reflection about terminology and theoretical research into the concept of citizenship education;

- to identify the basic skills required to practise democracy in European societies;

- to define the learning experiences and methods of EDC both within the school and in the context of lifelong learning;

- to identify and publicise examples of diversified practice in EDC;

- to explore the contribution of the media and new information technologies in disseminating the knowledge implicit in EDC, in setting up networks and data bases and disseminate innovative projects;

- to identify and support partnerships between the various environments and people involved in EDC: schools, parents, media, companies, local communities, youth organisations, adult education centers, political and cultural institutions etc.;

- to identify methods and strategies of training teachers and other trainers involved in EDC (Bîrzéa 2000)

As international organisations go, the Council of Europe is hardly a big fish: nevertheless, the EDC project (subsequently re-titled 'Education for Democratic Citizenship and Human 
Rights'), has provided a focus for a number of networks, conferences, seminars and publications, with policy, practice and research dimensions. ${ }^{5}$

Other international organisations have developed policy and research concerns relating to citizenship. Each reflects the particular organisation's perspective. As noted above, the European Commission's Directorate General for Research has supported a number of major projects in the area within its research framework programmes. In addition to projects related explicitly to 'citizenship', there are also a number which address related policy agendas, such as education for social inclusion and social cohesion, and others which incorporate analysis of citizenship within broader research on education. ${ }^{6}$ But the EU's impact on the 'knowledge base' is not limited to such major research projects alone. It supports a range of programmes, educational in the broad sense, from student exchange to town twinning, which often generate research reports, academic papers and evaluative reports. ${ }^{7}$

As Avril Keating shows in her paper below, EU and Council of Europe contributions can be traced back to their policy concerns; similar trajectories can be found in the work of other international organisations, and of national governments. In addition to the direct influence which the need for informed policy development and enhancement of educational practice has on research, the fashion for 'evidence-based' policy, and for measurement, indicators and targets, has been influential. We see this, for example, in the European Commission's project (2005-07) to develop 'indicators' of 'active citizenship' and 'education and training for active citizenship, ${ }^{8}$ and in the OECD Centre for Educational Research and Innovation's Understanding the Social Outcomes of Learning project. ${ }^{9}$ Similar policy concerns clearly lie behind the very influential and important work in this area of the International Association 
for the Evaluation of Educational Achievement (IEA), in particular its 1999 and 2009 comparative surveys of civic education and citizenship learning. ${ }^{10}$

The contributions to this special issue offer, we believe, some new insights into learning for citizenship. The papers draw on work from a number of disciplines including education, sociology, history, political science and management studies, and from different parts of the work (including Eastern Europe, Australia, the US and the UK).

As readers of Citizenship Studies will be aware, the growth in interest in citizenship as a political project over recent decades has come from both the right and the left of the spectrum. Those on the right have tended to be attracted by the dual emphasis that citizenship places on the individual's rights to pursue his or her own interests (without impediment from the state) and on the duties and obligations of individuals towards the state. While those on the left have often been sceptical of its value, sometimes seeing it as too closely entwined with capitalist endeavours, during the last two decades of the twentieth century various leftof-centre governments have sought to foreground the concept through a number of different policy measures (Faulks, 2000). This increasing interest can be attributed to a number of different, but often inter-related factors. In part, it is associated with the demise of the welfare state in many developed nations and a concomitant drive to encourage citizens to take increased responsibility for their own well-being, rather than relying on the state. Indeed, Landrum (2002) has argued that, within the UK, Labour's clear emphasis on the responsibilities of citizenship, as well as citizens' rights, has been part of a broader project to re-educate people that the state is an enabler, rather than a provider of services. It has also been seen as part of a response to the perceived problems of living in an increasingly multicultural and ethnically diverse society - by helping to foster social cohesion and a 
common sense of identity, as well as duties and obligations to a common community. Similarly, the emphasis placed on collective membership and responsibilities to others, central to many understandings of citizenship, is thought by some to offer a useful antidote to the worse excesses of societal individualism. It has also been driven by a concern that young people, in particular, lack the political knowledge and skills to act effectively as citizens, and are often not strongly embedded within their communities (Henn et al., 2005; Vromen, 2003). Finally, interest in citizenship (and, in particular, citizenship education) in some parts of the world can be seen to stem from the emergence of recently democratised states (such as South Africa and in Latin America, Central and Eastern Europe) and the need to enable their populations to understand the concepts of democracy and human rights (Osler and Starkey, 2003).

The heightened political profile given to the concept of citizenship across the globe has led to a number of specific initiatives aimed at inculcating particular types of citizenship. Within the realm of social policy, these have included 'citizenship ceremonies' and 'citizenship tests', both targeted primarily at immigrants taking up residence in a new country. However, the most commonly used policy tool used to develop citizenship is undoubtedly education broadly conceived, and including both formal and informal types of learning. Compulsory education, in particular, has been thought of as an effective vehicle for tackling some of the age-related problems outlined above, particularly young people's alleged political apathy, their disengagement from formal politics and their lack of knowledge about political institutions (Lister et al., 2005; Phelps, 2005). Young people have also been targeted through initiatives to encourage 'active citizenship' through community involvement and volunteering, while older learners have also been the focus of various programmes - at the local, national and regional level, within the workplace and across specific communities. 


\section{The 'learning society'}

Though our primary focus in this special issue is the recent upsurge of interest in citizenship education, the role of education in 'making citizens' is no recent discovery. In what has become a standard text, Heater (2004) traces the evolution of western civic education from classical Greece. He alludes to - though he does not explore - the Confucian contribution. Historians have often pointed to links between the growth of state education in the west and the extension of citizenship - whether understood in terms of the franchise or more broadly. In Britain, for instance, Robert Lowe famously advocated the 1870 Education Act as necessary for 'educating our future masters' (Reeder, 1980, p. 8). Lowe was no egalitarian; ${ }^{11}$ and though more radical views were to be found, the leading school citizenship text of the day emphasised duties and responsibilities (Arnold-Foster 1898).

The late Victorians also debated whether citizenship was best taught - by instruction in schools, evening classes or books - or 'caught', in boys' clubs, youth movements and the like. Half a century later, Richard Livingstone argued that both were over-rated. Civics should be taught, to be sure, but he saw a paradox: 'Youth studies but cannot act [as a citizen]; the adult must act, but has no opportunity to study' (p. 94). He was a strong advocate of adult education: this gave 'everyone a chance of thinking about life when he is facing it and about its problems when he has to solve them' (p. 95) Drawing on Aristotle's remark that 'men acquire virtues ... by practising them', however, he also emphasised the importance of key 'institutions whose members learn the habit of citizenship by being citizens', such as trades unions (p. 100). . 
This approach - similar thinking can be found in writers such as Dewey and Tawney - was strongly influenced by such movements as the Workers' Educational Association (WEA). During the Great War, the British Ministry of Reconstruction's Adult Education Committee argued that 'adult education is a permanent national necessity, an inseparable part of citizenship, and therefore should be both universal and lifelong' (Smith 1919, p. 5). While adult education provision has seldom matched these vaunting ideals, the notion that education should be lifelong became influential in the later twentieth century. In the 1970s, international organisations began to advocate notions such as the learning society and lifelong learning - most memorably in the Faure report (UNESCO 1972). By the 1990s these perspectives - suitably amended to fit the neoliberal politics of the times - dominated the thinking of international organisations such as the EU and the OECD, and were beginning to shape national education and welfare policies in the west (Field 2006).

What does a learning society (or lifelong learning) imply in relation to citizenship? It is, of course, a much contested concept. In one important tradition, the learning society comes close to an ideal of a good society: a society in which educational opportunities are available to all. "A democratic society, almost by definition, is an "educative society". ... Any good citizen is, perforce, a learner; the good society is an educative society' (Kidd 1961, 12). Lifelong education, as conceived in the Faure Report, came close to this view. A second view, however, sees societies as increasingly risky, globalised, and knowledge-based (cf Beck 1992, Giddens 1990); learning is a necessary element of individuals' capacity to be reflexive, and thus to adapt to unpredictability. This approach also draws on theories of reflective practice and reflective learning (Schön 1983). Others have pointed to a rhetorical dimension of lifelong learning: as adumbrated by governments in particular, it often involves 
expecting, encouraging or requiring citizens to learn - for example, through reforms of welfare or transforming learning into a desirable consumer commodity (Field 2006, Holford \& Jarvis 2000). Griffin (1999), for instance, noticed that 'where the reform of the welfare state is a primary political objective, lifelong learning, and other ways of achieving a "learning society" or a "learning culture", are to be discovered in the policy literature ... integrating it with other reform strategies which have the effect of making individuals less dependent upon the state.' (p. 451)

Edwards $(2002,2004)$ has argued that the resort to strategies of lifelong learning during the 1990s reflected states' changing attitudes to welfare and their citizens: governing is about mobilising people to help themselves, rather than providing services to them (Edwards 2002, p. 353). On this view, which draws on the work of Rose (1999a, 1999b), lifelong learning is seen as a 'technology of government': one which not only plays a part in governing society, but draws citizens into taking an active role in shaping themselves as responsible citizens. While this view probably exaggerates the effectiveness of such approaches (Ecclestone \& Hayes 2008, Holford 2006a), education in the learning society often has a strong affective dimension, seeking to reshape not only citizens' behaviour, but also their identities and emotions.

Lifelong learning, as it emerged in the neo-liberal climate of the 1990s, has often been criticised as excessively vocational: 'human resource development in drag' (Boshier 1998, 4). Certainly much lifelong learning has put a premium on learning in and for the workplace whereas earlier adult education movements had tended to emphasise learning to provide working people with in a broader, more humane, education. Policy literature typically stresses the importance of employment for effective participation in society, and of learning 
as key to developing and maintaining essential work-related skills (e.g., CEC 1995, DfEE 1999, Field 2006). One approach to encouraging 'active citizenship' stresses entrepreurial attitudes. An important strand of literature has also sought to explore how workplace learning affects citizenship - even as de facto a form of citizenship education. Catherine Casey's paper in this issue examines how contemporary models of economic organisation - such as the 'learning organisation' - shape the expression and learning of citizenship.

\section{Key debates in citizenship education research}

\subsection{The role of schools and lifelong learning}

Across the world, many governments have chosen to develop programmes for citizenship education and learning focussed their efforts on the school sector. In part, this can be explained by the relative ease of accessing large groups of people through such initiatives. The introduction of citizenship education as a compulsory component of the National Curriculum in England in 2002, for example, ensured that all young people under the age of 16 would receive some exposure to learning for citizenship by the time they finished school, and similar policies have been put in place in many other countries (Arthur et al., 2008). The schools-focus of much provision is also underpinned by the belief that it is young people who are perhaps most in need of citizenship education (as a result of their disengagement with formal politics, discussed above), and who may - by virtue of their age - be most inclined to change their behaviour and/or attitudes as a result. It has also been argued that citizenship education should be seen as part of a 'wider moralising agenda directed towards the "antisocial" behaviour of aberrant youth' (Gifford, 2004, p.148). 
Despite the key role assumed by schools, various empirical studies have pointed to significant practical impediments to teaching citizenship effectively through the compulsory sector including the status of the subject, inadequate training and support, and considerable variation in the level of teacher competence (Faulks, 2006; Kerr et al., 2004). A number of the contributions to this special address this theme. Indeed, those papers that focus primarily on citizenship education within schools point to some of the problems associated with the location of delivery. Bennett et al. emphasise the ways in which approaches to teaching in schools and colleges are often significantly out of step with young people's preferred learning styles - resulting in negative outcomes for civic learning, as well as for other subject areas. Similarly, Dimitrov and Boyadjieva argue that, within Bulgaria and other Eastern European countries, school education is often not relevant to contemporary life - which has considerable impact on the potential efficacy of citizenship education.

During the twentieth century, adult education was often closely bound up with working-class or nationalist movements; citizenship was implicit in its content and aims (Roberts 2003, Steele 2007, Freire 1972). Some, drawing on such experiences, came to adopt adult education (in the guise of community education or community development) as vehicle for encouraging the growth of citizenship, initially in colonial settings (Holford 1988, Whitehead 1997), later in urban regeneration in the west (Lovett 1975). Popular adult education movements such as the WEA advocated 'an education generous, inspiring and humane' for all (Tawney 1953, 34); in such movements, deeply influenced by the autodidacticism of their leaders, rigorous academic application was seen as the route to truth and understanding. Where adult education became a mechanism by which the state sought to establish or strengthen democratic institutions or practices, a tension has often arisen between the 'thick' conceptions of 
democracy, emphasising participation and dialogue, required to mobilise adult educational movements, and the more pragmatic demands of economic development and efficiency (Holford 2006b).

'Education is the best economic policy we have,' runs Tony Blair's epigraph to Britain's Learning Age white paper (DfEE 1998, 9) But, according to the then Secretary of State for Education and Employment, learning also 'helps make ours a civilised society, develops the spiritual side of our lives and promotes active citizenship' (DfEE 1998, 7). In general, however, economic aims have predominated in both policy literature and lifelong learning practice since the mid-1990s (Mitchell 2006, Robertson 2007, Taylor 2005). Casey's contribution to this special issue, exploring the impact of workplace learning on understandings of citizenship, illustrates this and explores its impact.

\subsection{Content of citizenship education programmes}

A key debate within both academic and policy-related literature on citizenship education focuses on the balance between what can be described as 'knowledge transmission', on the

one hand, and 'active citizenship' on the other. Some educationalists have strongly favoured prioritising an active approach to citizenship-learning, whereby young people are encouraged to take part in a wide range of practical activities, such as representing their fellow students on school councils and contacting their political representatives to discuss issues they feel strongly about (Davies and Evans, 2002; Ireland et al., 2006; Wilde, 2005). A commitment to 'active citizenship' underpinned the view of the Citizenship Advisory Group in the UK, which was set up to inform the citizenship curriculum, introduced as a compulsory component of the National Curriculum in 2002. Indeed, its recommendation that 'community 
involvement' should be a key strand of citizenship education was accepted by the government. This is defined as 'learning about and becoming helpfully involved in the life and concerns of communities, including learning through community involvement and service to the community' (QCA, 1998, p.11-13). This emphasis is replicated within citizenship education programmes in a number of other countries, including the US (Baldi et al., 2001) and Israel (Ichilov, 2008).

Measures to further 'active citizenship' have also emerged from outside the formal education sector - for example through various initiatives to encourage young people to take up volunteering within their communities (Annette, 2005; Matthews et al., 2009). Indeed, in the UK, the Labour government established the Russell Commission in 2004, with a specific remit to find ways to increase the take-up of voluntary work amongst the young and develop a National Framework for Youth Action and Engagement (Russell Commission, 2005). The article by Bennett et al. in this issue presents a strong theoretical justification for engaging young people actively through citizenship education. Indeed, they argue that the increasing availability of digital media, in particular, opens up many new and innovative avenues for young people - in schools and elsewhere - to practise their citizenship in very active ways. Similarly, Dimitrov and Boyajieva are broadly welcoming of more active approaches to citizenship education, suggesting that they can help to curb some of the particular problems witnessed in Bulgaria and other Eastern European countries.

Nevertheless, this emphasis on learning through engagement in forms of citizenship activity, and the strong encouragement of voluntary work (within the UK and US contexts, in particular), has not been universally welcomed. Indeed, Coffey (2004) has contended that such practices reflect an agenda that focuses on the skills and competencies necessary to 
make a contribution to the economy and the realignment of concepts of social and moral understanding, rather than more innovative and democratic understandings of citizenship. It has also been argued that the playing out of 'active citizenship' in the lives of young people is often strongly differentiated by gender, and tends to perpetuate traditional gender roles. Arnot and Dillabough (2000), for example, suggest that, for many young women, 'active citizenship' frequently means taking responsibility for themselves economically, while at the same time taking care of others. Young men, on the other hand, receive stronger encouragement to participate in a wider range of citizenship-related activities. They go on to claim that 'current conceptions of citizenship and democratic schooling not only endorse particular forms of masculinity, but serve, at least in part, to regulate the production of the citizen' (p.16).

In some ways, this has important elements of commonality with the wider debate about the respective weighting given to citizens' rights and responsibilities within citizenship education curricula (and also, of course, within approaches to citizenship more generally). While many educationalists have welcomed the emphasis on doing citizenship, rather than just learning about it, others have argued that the focus on active citizenship and an individual's responsibilities to his or her community has served to obscure the importance of rights. Indeed, Lister et al.'s (2005) empirical study of understandings of citizenship among young people in the UK has highlighted the ways in which, over the course of the last decade of the twentieth century, a rights-based discourse came to be replaced with one which stressed the importance of social responsibility and/or economic self-sufficiency. Moreover, they argue that the young people involved in their research found it much more difficult to identify their rights than their responsibilities. Scholars have also pointed out that not all types of 'activity' are equally valued by teachers, politicians and other adults and that, in some cases, this has 
led to the privileging of 'depoliticised' forms of citizenship (Ahier et al., 2003). In their analysis of responses to young people's participation in protests against the Second Iraq War in 2003, for example, Cunningham and Lavalette (2004) suggest that this form of community involvement was widely condemned by many of those in authority and seen as largely out of step with the forms of active citizenship encouraged by school curricula. They go on to argue that:

On the one hand, citizenship classes encourage children and young people to show a concern for 'the common good', to engage in 'active citizenry' and to accept the consequences of their actions; yet on the other hand, their 'reward' for proactively articulating their concerns over a major world crisis has been, on the whole, admonishment and ridicule. (p.265)

\subsection{Responding to social divisions}

As noted above, one of the drivers behind the implementation of citizenship education in many countries of the world has been a desire to respond to a number of perceived contemporary social problems. The increasing ethnic diversity of many societies and the ensuing tensions between different ethnic groups has been a particular focus of such initiatives. Nevertheless, while the potential of citizenship education to address social divisions in an effective manner has been widely stated, the capacity of citizenship education programmes - as currently conceived - to do so remains a key area of debate. Indeed, this constitutes the central focus of Preston's paper within this special issue. 
Within the UK context, Faulks (2006) has contended that structural inequalities within society - relating to gender differences as well as differences by ethnicity, religion and social class - warranted little discussion in the Crick Report (QCA, 1998), and that a coherent approach to such structural differences within the citizenship education curriculum is lacking as a result of the report's failure to recognise the conditions necessary to achieve equality. The shortcomings of the Crick Report in relation to tackling racial prejudice and discrimination have been highlighted by numerous writers (for example, Osler and Starkey, 2001 and Olssen, 2004), who have argued that ethnic diversity is presented largely as a problem to be managed within society rather than an integral and enriching part of it. This, it is claimed, is partially a result of the emphasis on national citizenship rather than post- or supra-national forms (Gifford, 2004) or education for global citizenship (Davies et al., 2005). Indeed, Faulks (2006) and Piper and Garratt (2004) go as far as to suggest that the form of multiculturalism that underpins the Crick Report can be understood as legitimizing or even engendering discrimination (for example, singling out individuals by celebrating their differences from others and not encouraging all pupils to engage in critical exploration of their own identities). Faulks concludes by arguing for a citizenship education based upon a fluid conception of identity that is multiple and dynamic in nature and 'an extensive element of anti-discriminatory education....which seeks to understand and reconcile difference in order to achieve equality for all individual citizens regardless of culture or ethnic origin' (p.65). Although this kind of critique has been made primarily with respect to 'race'/ethnicity, many of the same arguments can be extended to other forms of structural inequality, particularly in relation to the explicit foregrounding of anti-discriminatory education. 
Clearly an important component of this debate is about the principles that underpin citizenship education programmes and the ways in which they encourage pupils and teachers to conceptualise notions such as identity and difference. However, the literature also points to a number of more practical aspects of learning about citizenship that can have an important impact on the ways in which young people (and older learners) come to think about social divisions. Some feminist scholars have highlighted the potential of citizenship education to address gender inequalities (Arnot, 2008). Indeed, in their wider discussion of the experiences of young women across the Western world, Aaopla et al (2005) have argued that citizenship education programmes can provide valuable fora for contesting gendered power relations and their differential effect on young men and women from different class and ethnic groups, and for exploring the ways in which constructions of masculinity and femininity are dynamic and related to the public/private divide. However, as noted above, others have contended that the way in which citizenship is taught in many schools and colleges and, in particular, its emphasis on active involvement can help to perpetuate gender stereotypes - with young men and young women engaging in different types of activity (Roker and Eden, 2002) and being provided with few opportunities to reflect critically on these patterns (Hall and Coffey, 2007). Similar concerns are reflected across the globe. Miller-Idris (2005), for example, has outlined the difficulties for German teachers of addressing xenophobia and racism effectively as part of citizenship education programmes, as a result of some of the practical difficulties evident in schools, namely poor training, inadequate resources and lack of assistance for teachers within the classroom. Similarly, Ichilov (2003) argues that the perceived marginality of the subject in Israel (and the lack of a formalised, codified body of knowledge) significantly limits its ability to address national and religious divisions. 


\subsection{National or post-national citizenship}

A further key debate within the citizenship education literature relates to the nature and boundaries of the community to which citizenship refers. Typically, the nation state has been the focus of such programmes, and also the main driver behind them. As Osler and Starkey (2003) note, 'a major objective of education for national citizenship is to ensure that young people understand their present and future roles within the constitutional and legal framework of the state in which they live' (p.244). This is evident in numerous studies from different parts of the globe: in India, in the 1990s, citizenship education was used to recast the country in the image of a Hindu nation (Joshee, 2008); while Parmenter et al. (2008) claim that, in Japan, current education policy and curriculum 'allows very little room for identities or citizenship beyond the nation' and systematically privileges the national over the subnational, the transnational and the global (p.211). However, some scholars have argued that citizenship education programmes that maintain a solely national focus are increasingly likely to be undermined as the constructed nature of national identity becomes more evident, and people become more aware of the essentially artificial nature of the nation state (Bottery, 2003). Moreover, a strongly national policy focus has come under sustained attack from educationalists who believe that it promotes an ethno-centric approach, a failure to recognise diversity within nation states, a lack of understanding of international issues, and a tendency to treat non-nationals as 'Others' (Hahn, 2005). Furthermore, it is claimed that education for national citizenship often fails to engage with the actual experiences of young people, who, 'in a globalised world are likely to have shifting and multiple cultural identities and a sense of belonging that is not expressed first and foremost in terms of the nation' (Osler and Starkey, 2003, p.245). 
In response to some of these issues, many educationalists have argued that a more global focus needs to replace the dominant national emphasis within citizenship education - 'as a contribution towards the search for an elusive yet essential conception of global civic society' (Peters et al., 2008, p.2). For some, the alternative is education for post-national institutional citizenship, which recognises the increasing prevalence of multi-level governance. Here, citizenship education involves understanding and practising a more global citizenship within multiple sites of political membership. Others have suggested that citizenship education needs to move away from its focus on political institutions and emphasise, instead, the cultural components to citizenship identity. In developing this position, Gifford (2004) argues that a useful starting point is 'to consider the extent to which individuals are increasingly participants not in states and other territorial entities but discursive networks of contested information and knowledge' (p.155). This approach would draw upon young people's own political concerns and recognise their potential for establishing new forms of solidarity at the local, national and/or transnational level. This has much in common with Osler and Starkey's (2003) conception of 'cosmopolitan citizenship', which foregrounds the personal and cultural aspects of citizenship and focuses on 'enabling learners to make connections between their immediate contexts and the national and global contexts' (p.252). As well as recognising the multiple and dynamic identities (local, national and global) of young people, and international inter-dependencies, they argue that cosmopolitan citizenship encourages a much more sympathetic approach to social divisions observed and experienced locally:

It is insufficient ... to feel and express a sense of solidarity with others elsewhere if we cannot establish a sense of solidarity with others in our own communities, especially those whom we perceive to be different from ourselves. The challenge is to accept 
shared responsibility for our common future and for solving our common problems. It implies dialogue and peer collaboration to address differences of opinion.... (p.252).

Indeed, Osler and Starkey go on to contend that education then comes to assume a critical role in equipping young people with the knowledge, skills and attitudes to enable them to make a difference to the world in which they live.

These themes are addressed by several articles in this special issue. The national focus of much citizenship education is implicit in many of the contributions, but is foregrounded in the contributions by Preston, Macintyre and Simpson, and Keating. Preston focuses primarily on the use of citizenship education for purposes of national security, post-' $9 / 11$ ', while Keating is concerned to tease out the various ways in which European citizenship education initiatives have shifted away from a national to a post-national conception of citizenship in the last couple of decades. Macintyre and Simpson show some of the challenges involved in developing and delivering a national policy on citizenship education. In relation to some of the critiques of nationally-focussed programmes outlined above, she presents a largely upbeat analysis of the ways in which citizenship education can be based on membership of a political or civic community (which can recognise and value plurality both between and within nation states), rather than of an ethnic, historical or cultural community.

\section{Learning and citizenship}

As we have seen, the Victorians debated whether citizenship should be taught or 'caught': in modern terms, education or socialisation. Subsequent educational research has moved this 
debate forward. Where is it caught or taught? In the 1970s, Coombs proposed a typology of educational contexts: formal, non-formal and informal (Coombs 1985; Coombs \& Ahmad 1974). Formal and non-formal education refer to processes and institutions normally termed schooling and part-time education (or training) respectively, but 'informal education' referred to:

The life-long process by which every person acquires and accumulates knowledge, skills, attitudes and insights from daily experience and exposure to the environment at home, at work, at play; from the example and attitudes of family and friends; from travel, reading newspapers and books; or by listening to the radio or viewing films or television. Generally, informal education is unorganized, unsystematic and even unintentional at times, yet it accounts for the great bulk of any person's total lifetime learning - including that of a highly 'schooled' person. (Coombs and Ahmad 1974, p. $8)^{12}$

Learning society perspectives have highlighted the role of informal and non-formal learning contexts. The realisation that learning is not only conceptually different from teaching or education, but may often occur without any formal teaching 'input' whatever, has underpinned the outcomes-based or 'competency' approach to assessing learning. Informal and incidental learning of attitudes, values and skills are also central to citizenship education. 'Democratic, socially integrated and active citizens are not born, but are created (reproduced) in a socialisation process. ... [D]emocracy has to be learned and needs to be maintained' (Veldhuis 1997, p. 8). Nevertheless, despite the emphasis on participation and volunteering, citizenship education still tends to be thought of primarily as a matter of 'formal' education. 
Learning, however, is not just a matter of location: it involves processes leading to relatively lasting changes of capacity: motor, cognitive, emotional, motivational, attitudinal or social. Illeris focuses on three dimensions in particular:

Firstly all learning has a content of skill or meaning. The acquisition of this content is primarily a cognitive process .... Secondly, all learning is simultaneously an emotional process ... a process involving psychological energy, transmitted by feelings, emotions, attitudes and motivations .... Thirdly, learning is also a social process taking place in the interaction between the individual and its surroundings, and thus in the final analysis a process dependent on historical and societal conditions. (Illeris, 2002, p. 18)

Clearly learning citizenship in particular, with its dimensions of identity and action, must be emotional and social, as well as cognitive. Recent insights into the social nature of learning throw light on this. The notion that people play an active part in their own learning is wellestablished within the literature of adult education (cf Freire 1972; Jarvis 1987). People's active engagement is not only an advantage in enabling them to learn more effectively (Knowles 1980), but also means they play a part in constituting the knowledge which they learn (Lave \& Wenger 1991, Wenger 1998). At first glance, the importance of individuals' taking an active role in learning articulates well not only with Aristotle, but with contemporary notions of 'active citizenship'.

As Lave and Wenger (1991) emphasise, however, learners learn in social contexts. In their terminology, learners' 'situated learning activity' occurs within 'communities of practice'. Knowledge (or 'knowing') is located in the relations between learners, and in the 'social 
organisation and political economy of communities of practice' (p. 122). Whether consciously or accidentally, those who constitute a community of practice are organised in relations of power: these structure access, framing of issues, understandings of what is and what is not legitimate knowledge and appropriate behaviour, and so forth. In this special issue, Dimitrov and Boyadjieva use the metaphor of a battle: the communities within which people learn shape how and what they learn.

The recent trends in many countries for educational policies to emphasise learner autonomy may suggest an increasing openness to the informal and active dimensions of learning. School students should 'think for themselves'; generic, 'transferable' reasoning and analytical skills are more important than accumulating knowledge. However, learner autonomy is often constrained. In Britain, for example, there have been contradictory trends: increased central direction over the curriculum, a strong reaction against 'student-centred' learning methods, and an emphasis on making schools more accountable to their 'stakeholders' (principally, parents and business) (Holford \& van der Veen 2003). Dimitrov and Boyadjieva point in their article to the contradictions between the need for learning active citizenship to involve its practice, and the power relationships which structure education in Bulgaria.

\section{Citizenship, Learning and Education}

To the extent that citizenship is defined by what Poggi (1990) calls the 'particular bond' between the people and the state (p. 28), the rights and obligations it provides for vary from country to country, and over time. In the contemporary west, for instance, the requirement to pay taxes is widespread, the obligation to provide military service rather less common than 
formerly. In most western countries, several years' participation in education is now both an entitlement and an obligation - though the entitlement is typically to specific forms of education sanctioned by the state. Although states are also often encouraging participation in learning throughout life, it is seldom either an entitlement or an obligation (except for limited groups, such as migrants or the unemployed). The curriculum of compulsory education therefore plays a significant part in shaping the way citizens understand their role in society and polity.

By the same token, education now forms a major part of the activity and expenditure of most nation-states. They are increasingly explicit about what education should deliver: and in recent decades, in parallel with concerns about decreasing political engagement, especially among the young, citizenship has become an explicit feature of the curriculum. For this reason, states, and a wide range of non-state actors from international organisations to teachers, have had to think about the nature of citizenship and how it should be taught and learned. In other words, educational curricula have become important locations for the articulation and practice of discourses of citizenship. States' attempts to 'educate' their citizens are not limited to formal education, of course. Thus they often seek to shape workplace learning, typically in close liaison with business, to meet the demands of 'global competitiveness', and to shape attitudes to work among the unemployed.

However, citizenship is not defined only by people's relationship with the state; nor is education (still less learning) limited to the years of compulsory schooling. Citizens work, shop, are parents and friends, join clubs and societies, play sports, watch television: all these and more are expressions of their citizenship. In many, if not all, of these activities, they learn. Many citizens also join adult education classes, of course. The learning, whether 
incidental or through formal study, that they do in these situations may seem remote from any 'citizenship curriculum'. But in at least two respects it matters. Many non-state actors seek to play 'educational' roles: above all, perhaps, employers seek to shape the values and behaviour of workers, and how people practise their citizenship shapes what they learn: there is a 'hidden curriculum' in society at large, as well as in the school. 


\section{References}

Aapola, S., Gonick, M. and Harris, A. (2005) Young Femininity. Girlhood, Power and Social Change Basingstoke, Palgrave.

Ahier, J., Beck, J., Moore, R. (2003) Graduate Citizens? Issues of Citizenship and Higher Education London, RoutledgeFalmer.

Annette, J. (2005) Character, Civic Renewal and Service Learning for Democratic

Citizenship in Higher Education, British Journal of Educational Studies, 53, 3, 326340.

Arnold-Foster, H.O. (1886) The Citizen Reader London, Cassell.

Arnot, M. (2008) Educating the Gendered Citizen. Sociological engagements with national and global agendas London, Routledge.

Arnot, M. and Dillabough, J. (2000) Introduction, in: Arnot, M. and Dillabough, J. (eds) Challenging Democracy. International Perspectives on Gender, Education and Citizenship London, RoutledgeFalmer.

Arthur, J., Davies, I. and Hahn, C. (2008) (eds) The SAGE Handbook of Education for Citizenship and Democracy London, Sage.

Baldi, S., Perie, M., Skidmore, D, Greenberg, E. and Hahn, C. (2001) What Democracy Means to Ninth-Graders: US results from the International IEA Civic Education Study Washington, D.C., National Centre for Education Statistics, US Department of Education.

Beck, U. (1992) Risk Society London, Sage.

Bîrzéa, C. (2000) 'Education for Democratic Citizenship: A Lifelong Learning Perspective.' Strasbourg, Council of Europe (DGIV/EDU/CIT (2000) 21) Available at: http://www.coe.int/t/dg4/education/edc/Source/Pdf/Documents/2000_21_Birzea_Lifel ong_perspective.PDF (accessed 4 January 2009).

Boshier, R. (1998) Edgar Faure after 25 Years: Down but Not Out, in: J. Holford, P. Jarvis and C. Griffin (eds.) International Perspectives on Lifelong Learning London, Kogan Page, pp. 3-20. 
Bottery, M. (2003) The End of Citizenship? The nation state, threats to its legitimacy and citizenship education in the twenty-first century, Cambridge Journal of Education, $33,1,101-122$.

Campbell, D.E. (2006) What is education's impact on civic and social engagement? In Desjardins \& Schuller (eds.), pp. 25-126.

Coffey, A. (2004) Reconceptualising Social Policy. Sociological perspectives on contemporary social policy Maidenhead, Open University Press.

Colley, H., Hodkinson, P. and Malcolm, J. (2002) Non-formal learning: mapping the conceptual terrain. A consultation report. Leeds, Lifelong Learning Institute, University of Leeds.

Commission of the European Communities (CEC) (1995) Teaching and Learning: Towards a Learning Society Luxembourg, Office for Official Publications of the European Communities.

Council of Europe (2005) 'Education for Democratic Citizenship: Learning and Living Democracy' [leaflet]. Available at: http://www.coe.int/t/dg4/education/edc/Source/Pdf/Downloads/Leaflet_en.pdf (accessed 4 January 2009)

Coombs, P. (1985) The World Crisis in Education Oxford, Oxford University Press.

Coombs, P. \& Ahmed, M. (1974) Attacking Rural Poverty: How Nonformal Education Can Help. Baltimore, Johns Hopkins University Press.

Cunningham, S. and Lavalette, M. (2004) 'Active citizens' or 'irresponsible truants'? School student strikes against the war, Critical Social Policy, 24, 2, 255-269.

Davies, I. and Evans, M. (2002) Encouraging Active Citizenship, Educational Review, 54, 1, 69-78.

Davies, I., Evans, M. and Reid, A. (2005) Globalising Citizenship Education? A critique of 'global education' and 'citizenship education', British Journal of Educational Studies, $53,1,66-89$.

Delanty, G. (2003) Citizenship as a Learning Process: Disciplinary Citizenship versus Cultural Citizenship, International Journal of Lifelong Education 22, 6 (Special Issue on Citizenship, Democracy and Lifelong Learning), 597-605. 
Department for Education and Employment (DfEE) (1998) The Learning Age: a renaissance for a new Britain, Cm 3790, London, The Stationery Office.

Department for Education and Employment (DfEE) (1999) Learning to Succeed: a new framework for post-16 learning, Cm 4392, London, The Stationery Office.

Desjardins, R. \& Schuller, T. (eds.) (2006) Measuring the Effects of Education on Health and Civic Engagement. Proceedings of the Copenhagen Symposium. Paris: OECD CERI. Available at: http://www.oecd.org/dataoecd/23/61/37437718.pdf (accessed 4 January 2009).

Ecclestone, K. \& Hayes, D. (2008) The Dangerous Rise of Therapeutic Education. Abingdon, Routledge.

Edwards, R. (2002) Mobilizing lifelong learning: governmentality in educational practices. Journal of Education Policy 17, 3, 353-365.

Edwards, R. (2004) Mobilising Concepts: intellectual technologies in the ordering of learning societies. Pedagogy, Culture and Society 12, 3, 433-448.

Faulks, K. (2000) Citizenship London, Routledge.

Faulks, K. (2006) Education for citizenship in England's secondary schools: a critique of current research and practice, Journal of Education Policy, 21, 1, 59-74.

Field, J. (2006) Lifelong Learning and the New Educational Order, 2nd edition, Stoke on Trent, Trentham Books.

Freire, P. (1972) Pedagogy of the Oppressed Harmondsworth, Penguin.

Giddens, A. (1990) Consequences of Modernity Cambridge, Polity,

Gifford, C. (2004) National and Post-national Dimensions of Citizenship Education in the UK, Citizenship Studies, 8, 2, 145-158.

Green, A., Preston, J. and Janmaat, J.G. (2006) Education, Equality and Social Cohesion: A Comparative Analysis Basingstoke, Palgrave Macmillan.

Griffin, C. (1999) Lifelong learning and welfare reform. International Journal of Lifelong Education 18, 6, 431-452.

Hahn, C. (2005) US students becoming citizens: insights from the IEA civic education study, in: Wilde, S. (ed) Political and Citizenship Education. International Perspectives Oxford, Symposium Books. 
Hall, T. and Coffey, A. (2007) Learning selves and citizenship: gender and youth transitions, Journal of Social Policy, 36, 2, 1-18.

Heater, D. (2004) Citizenship: The Civic Ideal in World History, Politics and Education. $3^{\text {rd }}$ Edition. Manchester, Manchester University Press.

Henn, M., Weinstein, M. and Forrest, S. (2005) Uninterested youth? Young people's attitudes towards party politics in Britain, Political Studies, 53, 3, 556-578.

Hoffman, J. (2004) Citizenship Beyond the State London, Sage.

Holford, J. (1988) Mass education and community development in the British colonies, 19401960: A study in the politics of community education International Journal of Lifelong Education 7, 3, 163-183.

Holford, J. (2006a) The European Citizen in a Learning Society: Mobilised, Governed, or Active? In M. Kuhn (ed.) Who is the European? A New Global Player Frankfurt am Main, Peter Lang, 87-103.

Holford, J. (2006b) The role of lifelong learning in building citizenship: European Union approaches in the light of British and colonial experience International Journal of Lifelong Education 25, 3, 321-332.

Holford, J. (2008) Hard Measures for Soft Stuff: citizenship indicators and educational policy under the Lisbon Strategy, European Educational Research Journal 7, 3, 331-343.

Holford, J. \& Jarvis, P. (2000) The Learning Society. In: A.L. Wilson \& E.R. Hayes (eds.) Handbook of Adult and Continuing Education San Francisco, Jossey-Bass, 643-659.

Holford, J. and Veen, R. van der (2003) Lifelong Learning, Governance \& Active Citizenship in Europe: Final Report of the ETGACE Research Project. Guildford, UK, University of Surrey. Available at: ftp://ftp.cordis.europa.eu/pub/citizens/docs/hpse-ct-199900012etgace_eur21533final.pdf (accessed 9 January 2009).

Hoskins, B.L. \& Mascherini, M. (2009) Measuring Active Citizenship through the Development of a Composite Indicator, Social Indicators Research 90, 3, 459-488.

Hoskins, B., D’Hombres, B., \& Campbell, J. (2008) Does Formal Education Have an Impact on Active Citizenship Behaviour? European Educational Research Journal 7, 3, 386-402.

Hoskins, B., Jesinghaus, J., Mascherini, M., et al (2006) Measuring Active Citizenship in Europe. European Commission Directorate-General Joint Research Centre, Institute 
for the Protection and Security of the Citizen, Centre for Research on Lifelong Learning, Research Paper No. 4. Luxembourg: Office for Official Publications of the European Communities.

Hoskins, B., Villalba, E., Nijlen, D. van \& Barber, C. (2008) Measuring Civic Competence in Europe: a composite indicator based on IEA Civic Education Study 1999 for 14 year old in school. Luxembourg: Office for Official Publications of the European Communities.

Ichilov, O. (2003) Teaching civics in a divided society: the case of Israel, International Studies in Sociology of Education, 13, 3, 219-242.

Ichilov, O. (2008) Citizenship Education in Israel: a contested terrain, in: Arthur, J., Davies, I. and Hahn, C. (eds) The SAGE Handbook of Education for Citizenship and Democracy London, Sage.

Illeris, K. (2002) The Three Dimensions of Learning: Contemporary Learning Theory in the Tension Filed between the Cognitive, the Emotional and the Social Leicester, NIACE.

Ireland, E., Kerr, D., Lopes, J. and Nelson, J. with Cleaver, E. (2006) Active citizenship and young people: Opportunities, experiences and challenges in and beyond school London, DfES.

Jarvis, P. (1987) Adult Learning in the Social Context, London, Croom Helm.

Joshee, R. (2008) Citizenship Education in India: from colonial subjugation to radical possibilities, in: Arthur, J., Davies, I. and Hahn, C. (eds) The SAGE Handbook of Education for Citizenship and Democracy London, Sage.

Kerr, D. and Ireland, E. with Lopes, J, Graig, R. and Cleaver, E. (2004), Making citizenship real: citizenship education longitudinal study second annual report London, DfES.

Kidd, J.R. (1961) 18 to 80: Continuing Education in Metropolitan Toronto Toronto, Board of Education for the City of Toronto.

Knowles, M. (1980) The Modern Practice of Adult Education. Revised Edition, Chicago, Association Press.

Landrum, D. (2002), Citizenship, education and the political discourse of New Labour, Contemporary Politics, 8, 3, 219-232.

Lave, J. \& Wenger, E. (1991) Situated Learning: Legitimate Peripheral Participation Cambridge, Cambridge University Press. 
Lister, R., Smith, N., Middleton, S. and Cox, L. (2003) Young People Talk about Citizenship: Empirical Perspectives on Theoretical and Political Debates, Citizenship Studies 7, 2, 235-253.

Lister, R. with Smith, N., Middleton, S. and Cox, L. (2005) Young People and Citizenship, in Barry, M. (ed) Youth Policy and Social Inclusion Abingdon, Routledge.

Livingstone, R. (1943) Education for a World Adrift Cambridge, Cambridge University Press.

Lovett, T. (1975) Adult Education, Community Development and the Working Class London, Ward Lock Educational.

Lowe, R. (1980) Primary and Classical Education. In: Reeder (ed.) (1980).

Matthews, N., Green, P., Green, D. and Hall, I. (2009) The Role of Volunteering in the Transition from Higher Education to Work, in: Brooks, R. (ed.) Transitions from Education to Work: new perspectives from Europe and beyond Basingstoke, Palgrave.

Miller-Idris, C. (2005) Citizenship education and political extremism in Germany: an ethnographic analysis, in: Wilde, S. (ed.) Political and Citizenship Education. International Perspectives Oxford, Symposium Books.

Mitchell, K. (2006) Neoliberal governmentality in the European Union: education, training, and technologies of citizenship Environment and Planning D: Society and Space 24, 389-407.

Olssen, M. (2004) From the Crick Report to the Parekh Report: multiculturalism, cultural difference and democracy - the re-visioning of citizenship education, British Journal of Sociology of Education, 25, 2, 179-192.

OECD Directorate for Education (2007) Understanding the Social Outcomes of Learning. Paris, OECD.

Osler, A. and Starkey, H. (2001) Citizenship education and national identities in France and England: inclusive or exclusive? Oxford Review of Education, 27, 2, 287-305.

Osler, A. and Starkey, H. (2003) Learning for Cosmopolitan Citizenship: theoretical debates and young people's experiences, Educational Review, 55, 3, 243-254.

Parmenter, L., Mizuyama, M. and Taniguchi, K. (2008) Citizenship Education in Japan, in Arthur, J., Davies, I. and Hahn, C. (eds.) The SAGE Handbook of Education for Citizenship and Democracy London, Sage. 
Peters, M., Britton, A. and Blee, H. (2008) Introduction: Many Faces of Global Civil Society: Possible Futures for Global Citizenship, in: Peters, M., Britton, A. and Blee, H. (eds) Global Citizenship Education. Philosophy, Theory and Pedagogy Rotterdam, Sense Publishers.

Phelps, E. (2005), Young Voters at the 2005 British General Election, The Political Quarterly, 76, 4, 482-487.

Piper, H. and Garratt, D. (2004) Identity and Citizenship: some contradictions in practice, British Journal of Educational Studies, 52, 3, 276-292.

Qualifications and Curriculum Authority (QCA) (1998) Education for Citizenship and the Teaching of Democracy in Schools (The Crick Report), London, Qualifications and Curriculum Authority.

Reeder, D.A. (1980) Introduction. In: Reeder (ed.) (1980) Educating our Masters. Leicester, Leicester University Press.

Reeder, D.A. (ed.) (1980) Educating our Masters. Leicester, Leicester University Press.

Roberts, S. (ed.) (2003) A Ministry of Enthusiasm: Centenary Essays on the Workers' Educational Association London, Pluto Press.

Robertson S.L. (2007) Embracing the Global: Crisis and the Creation of a New Semiotic Order to Secure Europe's Knowledge-Based Economy, in: N. Fairclough, R. Wodak and B. Jessop (eds.) Education and the Knowledge-Based Economy in Europe, Rotterdam: Sense Publishers.

Rose, N. (1999a) Powers of Freedom: Reframing Political Thought Cambridge, Cambridge University Press.

Rose, N. (1999b) Governing the Soul. The Shaping of the Private Self $2^{\text {nd }}$ edition, London, Free Association Books.

Russell Commission (2005) A National Framework for Youth Action and Engagement, http://archive.cabinetoffice.gov.uk/russellcommission/report/index.html (Accessed $17 / 10 / 08)$

Schön, D. (1983) The Reflective Practitioner New York, Free Press. 
Smith, A.L. (1919) Covering letter from the Chairman to the Prime Minister. In: Ministry of Reconstruction, Adult Education Committee, Final Report, London, HMSO (Cmd $321)$.

Steele, T. (2007) Knowledge is Power! The Rise and Fall of European Popular Educational Movements, 1848-1939 Oxford, Peter Lang.

Tawney, R.H. (1953) A National College of All Souls. In: R.H. Tawney, The Attack and other papers London, George Allen and Unwin, 29-34.

Taylor, R. (2005) Lifelong learning and the Labour governments 1997-2004 Oxford Review of Education, 31, 1, 101-118.

UNESCO (1972) Learning to Be (The Faure Report) Paris, UNESCO.

Veldhuis, R. (1997) 'Education for Democratic Citizenship: dimensions of citizenship, core competencies, variables and international activities'. Paper presented to Council of Europe Council for Cultural Co-operation Project on Education for Democratic Citizenship Project Seminar. Strasbourg, Council of Europe.

Vromen, A. (2003) 'People try to put us down...': participatory citizenship of 'Generation X', Australian Journal of Political Science, 38, 1, 79-99.

Wenger, E. (1998) Communities of Practice Cambridge, Cambridge University Press.

Whitehead, C. (1997) 'When the Bush Takes Fire': A Study of the Origins and Purpose of Non-formal Education in British Colonial Policy, in: J. Lynch, C. Modgil, S. Modgil (eds.) Education and Development: Tradition and Innovation Vol. 4: Non-Formal and Non-governmental Approaches, London, Cassell, pp. 191-202.

Wilde, S. (2005) Papering over the cracks? Extra-curricular and cross-curricular citizenship learning in secondary schools in Germany, in: Wilde, S. (ed) Political and Citizenship Education. International Perspectives Oxford, Symposium Books.

\footnotetext{
${ }^{1}$ http://esj.sagepub.com/ (accessed 26 November 2008)

${ }^{2}$ http://www.citized.info/?strand=6 (accessed 26 November 2008)

${ }^{3}$ Illustrative examples under the Fifth and Sixth Framework research programmes are: 'Orientations of Young Men and Women to Citizenship and European Identity', 'Intercultural Active Citizenship Education' and 'Education and Training for Governance and Active Citizenship in Europe'. EU Framework Projects relating to citizenship address questions such as: How are social changes reshaping concepts, such as 'active citizenship' and 'governance'? Do women and men perceive citizenship differently? How can the education system intervene to teach governance and active citizenship? How do people construct their identities? Do they feel
} 
attached to their local area or their nation state? Do they consider themselves as European citizens?' (CEC website: http://ec.europa.eu/research/social-sciences/knowledge/article_3281_en.htm).

${ }^{4}$ While there is no adequate synoptic overview, Arthur, Davies \& Hahn (2008) is a substantial collection including a number of useful overviews of current work and of citizenship education in a range of countries. It concentrates on the initial and higher education sectors, saying little about adult edcuation.

${ }^{5}$ Thus, for example, the EDC's 'first phase' (1997-2000) was principally concerned with research; the second phase (2001-2004) was intended to 'translate the results of the first phase into concrete policies and practices' while 2005 became the 'European Year of Citizenship through Education' (Council of Europe 2005). Its website incorporates many research outputs, educational and policy materials (such as a 'pack' of 'practical instruments specifically designed to provide support to all those involved in education'). See http://www.coe.int/t/dg4/education/edc/Default_en.asp (accessed 4 January 2009).

${ }^{6}$ Current examples, under the Sixth Framework Programme, are the five-year integrated projects on 'Strategies for inclusion and social cohesion in Europe from education' (Includ-Ed) and 'Towards a Lifelong Learning Society in Europe: The Contribution of the Education System' (LLL2010) respectively.

${ }^{7}$ See http://ec.europa.eu/education/more-information/moreinformation294_en.htm (accessed 4 January 2009) and, for town-twinning, the 'Europe for Citizens' programme.

${ }^{8}$ The main outcomes of this project are set out in Hoskins \& Mascherini (2009), Hoskins, Jesinghaus, Mascherini et al. (2006), Hoskins, Villalba, Nijlen \& Barber (2008). See also Holford (2008), Hoskins, D'Hombres \& Campbell (2008), and other contributions to the European Educational Research Journal (Vol 7(3) 2008 - a special issue edited by Bryony Hoskins and Ruth Deakin Crick on 'Social Justice, Research and European Policy: defining and measuring key competences in education') and the papers presented at the European Commission Centre for Reserach on Lifelong Learning's conference on 'Working towards Indicators on Active Citizenship' (http://crell.jrc.ec.europa.eu/active citizenship.htm (accessed 4 January 2009)).

${ }^{9}$ See Campbell (2006), Desjardins \& Schuller (2006), OECD Directorate for Education (2007) and the Social Outcomes of Learning website

http://www.oecd.org/document/9/0,3343,en_2649 35845581_33706505 1_1_1_1,00.html (accessed 4 january 2009).

${ }^{10}$ The IEA's International Civic and Citizenship Education Study (ICCS) investigates 'the ways in which young people are prepared to undertake their roles as citizens in a range of countries in the 21 st century. In pursuit of this purpose, the study will report on student achievement in a test of knowledge, conceptual understanding and competencies in civic and citizenship education. It will also collect and analyse data about student dispositions and attitudes relating to civics and citizenship. The study builds on the previous IEA studies of civic education, particularly CIVED in 1999.... The population to be studied is students in Grade 8 (on average including students who are approximately 14 years of age) .... Grade 8 is a stage of secondary schooling in which participation is universal in most countries and which has the greatest similarity in organisational contexts across countries.... The survey of teachers will be from the same schools as the students and there will be a survey of the principals (or head teachers) in those schools. The minimum sample for a country will be 150 schools with about 3,500 students.' (International Civic and Citizenship Education Study Information Brochure, available at: http://iccs.acer.edu.au/uploads/File/ICCS\%20Information\%20Brochure(1).pdf) (Accessed 26 November 2008). Conducted between October 2008 and April 2009, the following countries participated: Austria, Belgium (Flemish), Bulgaria, Chile, Chinese Taipei, Colombia, Cyprus, Czech Republic, Denmark, Domincan Republic, England, Estonia, Finland, Greece, Guatemala, Hong Kong SAR, Indonesia, Ireland, Italy, Korea, Latvia, Lichtenstein, Lithuania, Luxembourg, Malta, Mexico, Netherlands, New Zealand, Norway, Paraguay, Poland, Russian Federation, Slovak Republic, Slovenia, Spain, Sweden, Switzerland, Thailand (http://www.iea.nl/icces.html (Accessed 26 November 2008)).

${ }^{11}$ In a lecture to the Edinburgh Philosophical Institute in 1867, Lowe argued: 'The lower classes ought to be educated to discharge the duties cast upon them. They should also be educated that they may appreciate and defer to a higher cultivation when they meet it; and the higher classes ought to be educated in a very different 
manner, in order that they may exhibit to the lower classes that higher education to which, if it were shown to them, they would bow down and defer.' (Lowe 1980, pp. 125-126)

${ }^{12}$ According to Coombs, formal education and training occurs in school and post-school institutions, typically in the public sector, and is the major mechanism of public intervention in education. It is characterised by relatively centralised, stable and sequential curricula, and well-established structures of assessment. It is the main locus of most state 'civic education' policies and expenditure. Non-formal education is systematic educational activity outside formal system (e.g. work-based training, community education programmes in health, co-operation, etc., adult literacy programmes). It has been the main traditional source of state intervention in post-school learning, and the main context for provision by NGOs, SMEs and the voluntary sector. Informal education is unorganised, unsystematic and/or unintended lifelong learning, e.g. from home, work, and media. It is the source of most learning over a lifetime, but the outcomes are strongly dependent on individuals' learning environments. (Coombs 1985, esp. pp. 20-26.) In a major attempt to review and clarify the literature on classifications of formal, non-formal and informal education, Colley et al. (2002) contest such classifications. They argue that it is often the 'blending of formal and informal' which leads to the most significant learning; that there are 'few, if any, learning situations where either informal or formal elements are completely absent' (p. 6), and that 'either the boundaries between formal, non-formal and informal learning or education, or the relationships between them, can only be understood within particular contexts' which have 'historical, economic, social and political dimensions'. (Colley et al. 2002, p. 7) 